\title{
Leishmania (Viannia) braziliensis infection in two Colombian dogs: a note on infectivity for sand flies and response to treatment
}

\author{
Bruno L. Travi, Carlos Javier Tabares, Horacio Cadena \\ Centro Internacional de Entrenamiento e Investigaciones Médicas, Cali, Colombia.
}

Introduction. Although canine cutaneous leishmaniasis has been reported in several foci of South America, no published information from Colombia is available.

Objective. We report on two cases found in the Pacific coast region of this country, which presented as a single scrotal ulcer in one dog, and two ulcers on the external surface of the ear in a second dog.

Materials and methods. Parasites were isolated by culture in Senekjie's culture medium and identified using monoclonal antibodies. The capacity of these dogs to transmit the parasites to sand fly vectors (Lutzomyia trapidoi, Lutzomyia gomezi, Lutzomyia longipalpis, Lutzomyia youngi) was tested by allowing the flies to feed on the lesion borders.

Results. Both isolates were identified as Leishmania (Viannia) braziliensis. No infections were detected upon dissection of engorged flies. A single peri-and sub-lesional injection of 1-2 $\mathrm{ml}$ of pentavalent antimony in the dog with ear lesions resulted in clinical cure 6 weeks post-treatment. Conclusions. These observations suggest that although dogs are susceptible to L. braziliensis, their reservoir competence could be low. However, if further studies indicate that canines are capable reservoir hosts of $L$. Viannia spp., the local treatment of lesions could become a feasible approach to diminish the risk of human infection in the peridomestic setting, without sacrificing infected dogs.

Keywords: Leishmania braziliensis, dog diseases, cutaneous leishmaniasis, Leishmania reservoir, therapy

Infección por Leishmania (Viannia) braziliensis en dos perros colombianos: una nota sobre infectividad para flebótomos y respuesta al tratamiento.

Introducción. A pesar de que la leishmaniasis cutánea canina ha sido reportada en varios focos de Sudamérica, no existe información publicada de Colombia.

Objetivo. Se reportan dos casos hallados en la región de la costa Pacífica de este país, que se presentaron como una úlcera escrotal única en un perro y como dos úlceras en la cara externa de la oreja en un segundo individuo.

Materiales y métodos. Los parásitos fueron aislados por cultivo en medio de Senekjie e identificados empleando anticuerpos monoclonales. La capacidad de los perros para transmitir parásitos a los flebótomos vectores (Lutzomyia trapidoi, Lutzomyia gomezi, Lutzomyia longipalpis, Lutzomyia youngi) se ensayó permitiendo que los insectos se alimentaran sobre el borde de las lesiones.

Resultados. Ambos aislamientos se identificaron como Leishmania (Viannia) braziliensis. No se detectaron infecciones durante la disección de los flebótomos alimentados. Una sola inyección peri- y sub-lesional de 1-2 $\mathrm{ml}$ de antimonio pentavalente en el perro con las lesiones auriculares resultó en la curación clínica a las 6 semanas post-tratamiento.

Conclusiones. Estas observaciones sugieren que aunque los perros son susceptibles a $L$. braziliensis, su competencia como reservorio podría ser baja. Sin embargo, si estudios posteriores demuestran que los caninos tienen capacidad de reservorio para especies de $L$. Viannia, el tratamiento local de las lesiones podría ser una estrategia factible para disminuir el riesgo de infección humana en el peridomicilio, sin necesidad de sacrificar a los perros infectados. 
Palabras clave: Leishmania braziliensis, leishmaniasis cutánea, enfermedades de los perros, terapia

The natural infection of dogs with Leishmania (Viannia) spp. in rural and periurban areas of South American countries such as Argentina, Brazil, Perú and Venezuela has been reported by several authors (1-8). However in Colombia, where three species of Leishmania (Viannia) are endemic (9), no published information on canine cutaneous leishmaniasis is available.

There is no doubt that dogs play an essential role in the peridomestic transmission of visceral leishmaniasis (10), yet only risk factor analyses and isolation of Leishmania from lesions have suggested that they could play a role in American cutaneous leishmaniasis $(1,7,11)$, and consequently confirmatory studies are still pending. We report on two cases of canine leishmaniasis in adult male, mongrel dogs residing in different endemic areas of cutaneous leishmaniasis in the Colombian Pacific coast.

\section{Materials and methods}

The first individual suspicious of having cutaneous leishmaniasis, an adult male, was found during a dog screening for American cutaneous leishmaniasis ( $\mathrm{n}=52$ dogs) in the municipality of Tumaco, Nariño $\left(1^{\circ} 48^{\prime} \mathrm{N}, 78^{\circ} 46 \mathrm{~W}\right)$, an area endemic for cutaneous leishmaniasis. The animal, which was the only individual with lesions, had a chronic scrotal ulcer of unknown evolution time. The second dog, also an adult male, resided in Bajo Calima, municipality of Buenaventura $\left(4^{\circ} 2^{\prime} \mathrm{N}, 77^{\circ} 4^{\prime} \mathrm{W}\right)$, a small rural town distant $30 \mathrm{~km}$ from the Pacific coast in the department of Valle del Cauca. It was brought to CIDEIM for diagnosis, presenting a large ulcer and a satellite lesion on the external face of the ear, of less than 6 months of evolution (figure 1a). Dermal scrapings stained with $2 \%$ Giemsa and aspirate-cultures $(n=4)$ seeded in Senekjie's culture medium of samples obtained from the lesion borders were used as diagnostic

\section{Corresponding:}

Bruno L. Travi, CIDEIM, Apartado Aéreo 5390, Cali, Colombia. Telephone: (572) 668 2164; fax: (572) 6672989

travib@cideim.org.co

Recibido: 11/04/05; aceptado: 23/06/05 methods (12). To test the capacity of these dogs to transmit Leishmania to sand flies, the animals were subjected to xenodiagnosis. For this purpose, Lutzomyia trapidoi and Lutzomyia gomezi, which are the prevalent sand fly species in this region (13), were collected in the field, and groups of $50-100$ female flies were caged in 500 $\mathrm{ml}$ plastic containers furnished with fine mesh. The dogs were anesthetized with xylacine $(2 \mathrm{mg} /$ $\mathrm{kg}$; Rompun $\AA$, Bayer) and the lesion borders exposed for 30 ' to the bites of sand flies. Between 30 and 40 flies took a blood meal on each dog.

The individual with the ear lesions also was exposed to colonized Lutzomyia longipalpis $(\mathrm{n}=20$ engorged), the common Leishmania infantum (= L. chagasi) vector in the Americas, which is widely used as experimental vector for several Leishmania species including Leishmania (Viannia) spp. (14). Also, wild-caught Lutzomyia youngi $(n=10$ engorged), a natural vector of cutaneous leishmaniasis in South America, was used in the latter individual $(15,16)$. Engorged flies were maintained on a sugar water diet, and dissected 6-7 days postfeeding, when parasites regularly multiply and migrate to the anterior midgut and stomodeal valve (17).

\section{Results}

Although no amastigotes were detected in either dog by microscopic examination of dermal scrapings, promastigotes readily grew in Senekjie's culture medium after one week of incubation at $25^{\circ} \mathrm{C}$. Both isolates were identified as Leishmania braziliensis using a panel of monoclonal antibodies that discriminates between different species of the subgenus Viannia (18). No gut infections with Leishmania promastigotes were detected in any of the sand flies fed on either dog upon individual dissection of the flies.

Only the dog with ear lesions was available for treatment, and based on previous reports of successful local therapy we decided to apply a similar approach. Between 1 and $2 \mathrm{~mL}$ of meglumine antimoniate (Glucantime $\AA$ ) were injected subcutaneously at different sites around and under the lesions. Although only one injection 

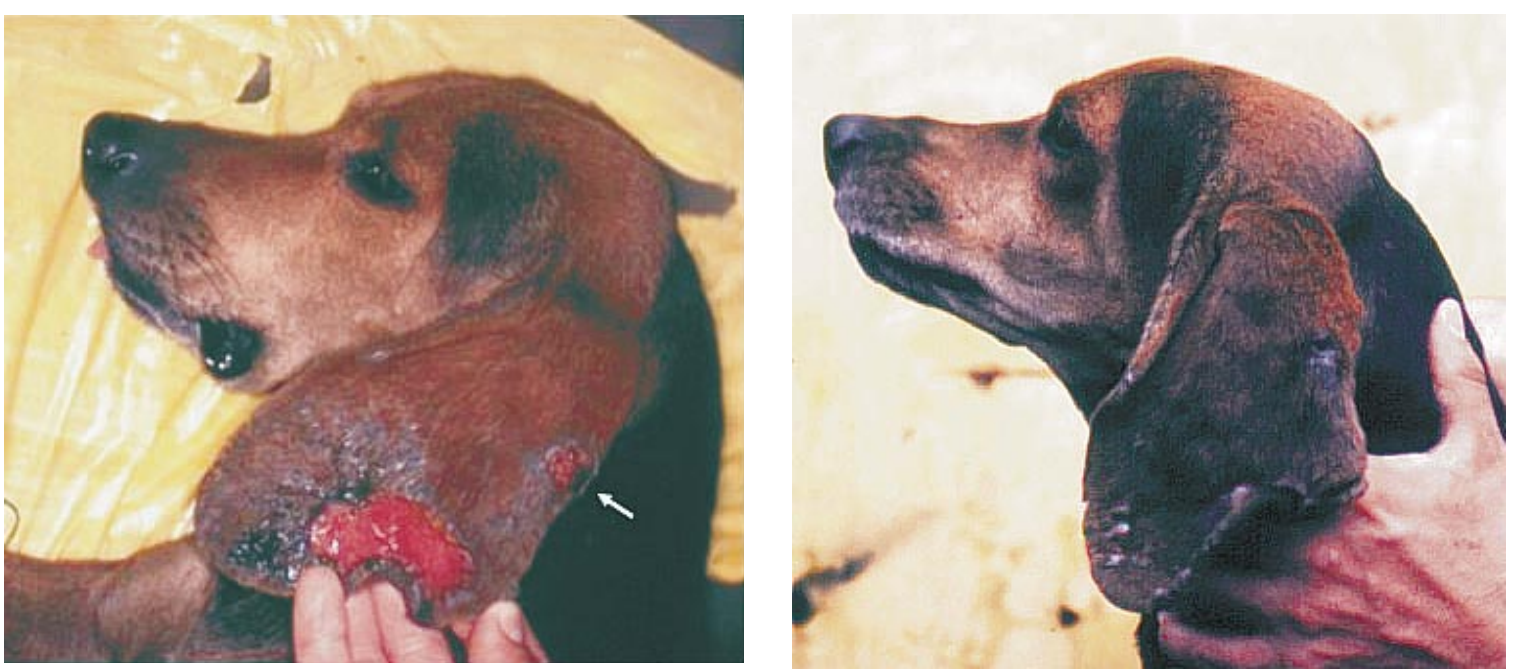

Figure 1. Cutaneous leishmaniasis due to Leishmania (Viannia) braziliensis in a mongrel dog. A primary ulcer and small satellite lesion (arrow) on the external surface of the ear were present at the time of diagnosis (left). Clinical cure was achieved in approximately 6 weeks after a single peri-lesional injection of pentavalent antimony was applied (right).

was applied, the ulcers began to heal 15 days after treatment and clinical resolution was achieved in approximately 6 weeks, with hair regrowth and only a small, flat scar (figure 1b). Aspirates from the scar obtained at this time point were negative by culture; no clinical follow-up of this individual was possible beyond this period.

\section{Discussion}

The results suggest that despite the fact that canines are susceptible to $L$. braziliensis, developing cutaneous lesions, their reservoir status in American cutaneous leishmaniasis should be evaluated in greater detail if control measures targeted at this species are to be applied. Vexenat et al. (19) were capable of infecting a low proportion of Lutzomyia whitmani (1.8-8.3\%) by feeding them on the lesions of $3 / 9$ dogs naturally infected with L. braziliensis.

It is conceivable that our negative results were due to the low number of amastigotes present in the lesions, as suggested by the absence of parasites in the dermal scrapings. On the other hand, it is feasible that the number of sand flies fed on the dogs $(<50)$ per xenodiagnosis was insufficient to detect truly infective individuals.

More recent work in our laboratory involving patients with cutaneous leishmaniasis suggested that xenodiagnoses carried out with less than 50 engorged flies have low sensitivity, even in patients showing large numbers of amastigotes in the lesions (CIDEIM, unpublished). Therefore, negative xenodiagnoses obtained upon dissection of fewer than 50 sand flies should be interpreted with caution.

Nevertheless, the observations made on these two dogs contrasted with xenodiagnoses performed on dogs infected with $L$. infantum in which parasites are readily transmitted to sand flies, including non-natural vector species (20-22). In our case, the low reservoir competence was emphasized by the negative results obtained with Lutzomyia trapidoi, L. gomezi, and L. youngi, which are proven vectors of cutaneous leishmaniasis $(13,15)$, and have shown to acquire Leishmania at high rates (37-44\%) after feeding on laboratory animals experimentally infected with $L$. Viannia (23; CIDEIM unpublished).

It is interesting to note that in the Pacific coast region of Colombia Leishmania (Viannia) panamensis accounts for the majority $(>90 \%)$ of human cases (24), but the only two dogs that we have found with skin ulcers were infected with $L$. braziliensis. Although this may be a fortuitous observation, further field and experimental studies are necessary to assess dog susceptibility to 
Leishmania (Viannia) spp. and establish the reservoir role in Colombian foci of American cutaneous leishmaniasis. Studies in Brazil have shown that the majority of lesions were localized on the ears ( $63.6 \%$ of all lesions detected), and this may have epidemiological implications because in other Leishmania species ( $L$. infantum) we determined that transmission to sand flies was more efficient at this site than in other body areas $(21,25)$.

Systemic and local therapy for canine cutaneous leishmaniasis using pentavalent antimonials have resulted in cure rates ranging from 80.9 to $86.6 \%$, however in the intramuscular treatment clinical resolution was followed by recurrence in a high percentage of animals $(>40 \%)(5,25)$. Clinical cure, even in the absence of parasite clearance, could be beneficial to reduce potential reservoir competence. Therefore, if canines prove to be efficient sources of Leishmania for the natural vectors, treatment of skin ulcers with local injections of pentavalent antimonials could become a reasonable approach to diminish the risk of human infection in the peridomestic setting without sacrificing infected dogs.

\section{Conflict of interests}

The authors of the present article declare that there are no conflicts of interest that may have influenced the results of this work.

\section{Financing}

This study was partially supported by TMRC grant $n^{\circ}$ I-P50 AI 30603-03, and CIDEIM.

\section{References}

1. Padilla AM, Marco JD, Diosque P, Segura MA, Mora MC, Fernández MM et al. Canine infection and the possible role of dogs in the transmission of American tegumentary leishmaniosis in Salta, Argentina. Vet Parasitol 2002;110:1-10.

2. Sherlock IA, Maia H, Dias-Lima AG. Preliminary results of a project about the ecology of Phlebotomus vectors of cutaneous leishmaniasis in the State of Bahia. Rev Soc Bras Med Trop 1996;29:207-14.

3. Nunes MP, Jackson JM, Carvalho RW, Furtado NJ, Coutinho SG. Serological survey for canine cutaneous and visceral leishmaniasis in areas at risk for transmission in Rio de Janeiro where prophylactic measures had been adopted. Mem Inst Oswaldo Cruz 1991;86: 411-7.
4. Aguilar CM, Rangel EF, García L, Fernández E, Momen H, Grimaldi Filho G, et al. Zoonotic cutaneous leishmaniasis due to Leishmania (Viannia) braziliensis associated with domestic animals in Venezuela and Brazil. Mem Inst Oswaldo Cruz 1990;84:19-28.

5. Barbosa Santos EG, Marzochi MC, Conceicao NF, Brito CM, Pacheco RS. Epidemiological survey on canine population with the use of immunoleish skin test in endemic areas of human American cutaneous leishmaniasis in the State of Rio de Janeiro, Brazil. Rev Inst Med Trop Sao Paulo 1998;40:41-8.

6. Reithinger R, Espinoza JC, Davies CR. The transmission dynamics of canine American cutaneous leishmaniasis in Huanuco, Peru. Am J Trop Med Hyg 2003; 69:473-80.

7. Reithinger R, Canales Espinoza J, Llanos-Cuentas A, Davies CR. Domestic dog ownership: a risk factor for human infection with Leishmania (Viannia) species. Trans R Soc Trop Med Hyg 2003;97:141-5.

8. Serra CMB, Leal CA, Figueiredo F, Schubach TM, Duarte R, Uchôa CMA et al. Canine tegumentary leishmaniasis in Morada das Águias (Serra da Tiririca), Maricá, Rio de Janeiro, Brazil. Cad Saúde Pública 2003;19:1877-80.

9. Saravia NG, Holguín AF, McMahon-Pratt D, D'Alessandro A. Mucocutaneous leishmaniasis in Colombia: Leishmania braziliensis subspecies diversity. Am J Trop Med Hyg 1985;34:714-20.

10. Tesh RB. Control of zoonotic visceral leishmaniasis: is it time to change strategies? Am J Trop Med Hyg 1995;52:287-92.

11. Reithinger R, Davies CR. Is the domestic dog (Canis familiaris) a reservoir host of American cutaneous leishmaniasis? A critical review of the current evidence. Am J Trop Med Hyg 1999;61:530-41.

12. Escobar MA, Martínez F, Scout Smith D, Palma GI. American cutaneous leishmaniasis (tegumentary): a diagnostic challenge. Trop Doc 1992;22(Suppl.1):69-78.

13. Travi BL, Montoya J, Solarte Y, Lozano L, Jaramillo C. Leishmaniasis in Colombia. I. Studies on the phlebotomine fauna associated with endemic foci in the Pacific Coast region. Am J Trop Med Hyg 1988;39:261-6.

14. Da Silva AL, Williams P, Melo MN, Mayrink W. Susceptibility of laboratory-reared female Lutzomyia longipalpis (Lutz \& Neiva, 1912) to infection by different species and strains of Leishmania Ross, 1903. Mem Inst Oswaldo Cruz 1990;85:453-8.

15. Feliciangeli MD. Vectors of leishmaniases in Venezuela. Parassitologia 1991;33(Suppl):229-36.

16. Rojas E, Scorza JV. Xenodiagnóstico con Lutzomyia youngi en casos venezolanos de leishmaniasis cutánea por Leishmania braziliensis. Mem Inst Oswaldo Cruz 1989;84:29-34. 
17. Walters LL. Leishmania differentiation in natural and unnatural sand fly hosts. J Eukaryot Microbiol 1993;40:196-206.

18. McMahon-Pratt D, Bennett E, David JR. Monoclonal antibodies that distinguish subspecies of Leishmania braziliensis. J Immunol 1982;129:926-7.

19. Vexenat JA, Barretto AC, Rosa A de C. Experimental infection of Lutzomyia whitmani in dogs infected with Leishmania braziliensis braziliensis. Mem Inst Oswaldo Cruz 1986;81:125-6.

20. Molina R, Amela C, Nieto J, San Andrés M, González F, Castillo JA, et al. Infectivity of dogs naturally infected with Leishmania infantum to colonized Phlebotomus perniciosus. Trans R Soc Trop Med Hyg 1994;88:491-3.

21. Travi BL, Tabares CJ, Cadena H, Ferro C, Osorio Y. Canine visceral leishmaniasis in Colombia: relationship between clinical and parasitological status, and infectivity to sand flies. Am J Trop Med Hyg 2001;64: 119-24.
22. Travi BL, Ferro C, Cadena H, Montoya-Lerma J, Adler GH. Canine visceral leishmaniasis: dog infectivity to sand flies from non-endemic areas. Res Vet Sci 2002;72:83-6.

23. Jaramillo C, Travi BL, Montoya J. Vector competence of some Neotropical sandflies for the Leishmania (Viannia) braziliensis complex. Med Vet Entomol 1994;8:1-7.

24. Weigle KA, Saravia NG, de Davalos M, Moreno LH, D'Alessandro A. Leishmania braziliensis from the Pacific coast region of Colombia: foci of transmission, clinical spectrum and isoenzyme phenotypes. Am J Trop Med Hyg 1986;35:722-31.

25. Pirmez C, Coutinho SG, Marzochi MC, Nunes MP, Grimaldi G Jr. Canine american cutaneous leishmaniasis: a clinical and immunological study in dogs naturally infected with Leishmania braziliensis braziliensis in an endemic area of Rio de Janeiro, Brazil. Am J Trop Med Hyg 1988;38:52-8. 